\title{
DIRECTORS REMUNERATION AND COMPANIES' PERFORMANCE THE COMPARISON OF LISTED COMPANIES IN POLAND AND UK
}

\author{
Agnieszka HERDAN*, Katarzyna SZCZEPAŃSKA** \\ *Accounting \& Finance Department \\ University of Greenwich, Park Row, London SE10 9LS \\ e-mail: a.herdan@gre.ac.uk \\ **Faculty of Management \\ Warsaw University of Technology, Warsaw, Poland \\ e-mail: k.szczepanska@wz.pw.edu.pl
}

\begin{abstract}
This paper examines the determinants of CEO compensation. There are many factors that influence CEO compensation. For this research three factors has been selected: companies size, accounting factor and market factor. The study looks at the relationship between each of this factors and directors remuneration. Sample of companies listed on London Stock Exchange (LSE) and Warsaw Stock Exchange (WSE) has been investigated over the period of 2007 - 2010. Data has been collected through annual reports content analysis and announcement on websites of LSE and WSE. Linear regression has been run on collected data. Positive correlation has been found between directors' remuneration and companies' size in both British and Polish listed companies. The relationship is also positive between directors pay and companies performance. Companies' performance has been assets by return on equity ratio (ROE) and Tobin's Q. All the findings are consistent with the outcome presented within previous research by variety of scholars.
\end{abstract}

Key words: corporate governance, companies' performance, director's remuneration, agency cost, CEO compensation.

\section{Introduction}

Corporate governance was first introduced by A. Smith. He highlighted the changes in companies' behaviour as a consequence of separation of ownership and control. There is an ongoing debate at present how corporate governance should be define (Jarzemowska [13], pp. 22-34). The concept of corporate governance can be looked at form legal and economic perspective. Economic approach describe corporate governance as "an institutional mechanism for regulating the relationship between the participants of corporate contracts, especially between managers and shareholders (...). It is a set of principles affecting the supervision and accountability of the company." (Ignyś-Lipowiecka [12], pp. 215-216).

Corporate governance is strictly related with:

- accountability - the way in which managers are accounttable to shareholders,

- communication - how the company obtain and communicate information,

- relationships - diversified in terms of economic conditions and national traditions, between the owners and managers of corporations.

The main aim of corporate governance is to protect shareholders interest against misused of their capital by managers of a company. The rationale for the use of these practices may be the fact that the principles of corporate governance are an important factor when assessing a company. It could affect the valuation of the company or influence the investment decision of potential investor.

The models of corporate governance are the formal systems of accountability of top management to shareholders and they that should create an integrated value for the shareholder. These models are based on two assumptions:

- maximization of shareholder value is the best way to ensure their prosperity,

- financial goals can be achieved by building long term relationships with all stakeholders.

This allows to regard relationships with employees, customers, investors, suppliers and the community as an essential source for improving companies competitiveness. Good relationship is understood as value of information, reputation, contracts. The model of stakeholders groups (a network of formal and informal relationships of corporations - a pluralistic approach) is based on the assumption that the company is a social institution and therefore can extend its influence on the prosperity of society and brings benefits not only to shareholders but also to wide groups 
of other parties, as many companies may spend part of their profits on social objectives. This shows the direct connections "between social obligations, social responsibility and corporate social response." (Kopycińska [17], p. 197).

The UK represent single tire corporate governance model. The major role is played by The Board of Director (executive and non-executive), who are elected at General Annual Meeting (AGM). The role of Board of Director is to manage the company on behalf of and in the best interest of shareholders (GajewskaJedwabny [7], p. 492). On the other hand Polish capital marked is at quite early stage of developing corporate governance practice. The corporate governance principled main aim is to prevent some negative phenomena, such as fraud or violations of rights of minority shareholders (Gajewska-Jedwabny [7], p. 502).

Solarz ([26], p. 274) stress that as Anglo - Saxon model has a strong relationship between the remuneration of director and company performance, for Polish companies the remuneration of directors grow faster than profit, return on assets (ROA) and return on capital employed (ROE).

The recent academic debate within corporate governance concentrates on the relationship between CEO remuneration ${ }^{1}$ and companies' performance. Investors are becoming more and more concern by companies' mismanagement after a series of corporate scandal such as Enron, World Com, Parmalat, Maxwell, Polly Peck etc. "Investors are shocked and apprehensive after recent news about huge payment of $£ 1,7$ billion in bonuses to the managers of RBS (Royal Bank of Scotland) despite bank making a $£ 3,6$ billion loss during 2009" (Seel [24]). This example shows the inconsistency of classical compensation theory, as only improved performance should be awarded by higher remuneration. Investors start questioning high paid management contracts as being unreasonable more often than ever.

The problem with discrepancies between managers' compensation and investors' expectation is strongly address by agency theory and has been investigated by many researchers in the last three decades (Jensen et al. [14], pp. 255-268; Kato et al. [16], pp.1-19; Oetomo et al. [20]). According to agency theory principal - agent relationships is a contract under which one

\footnotetext{
${ }^{1}$ For the purpose of this paper compensation, remuneration, salary, pay, payment will be used as synonyms and will describe the total value of reward allocated to the directors.
}

or more persons (the principal engage another person the agent) are engaged to perform some service on their behalf which involves delegating some decision making authority to the agent. For this services and contribution to shareholders wealth the agents are expecting to be properly rewarded, but the agents for obvious reasons do not always act in a way which contributes to maximising shareholders' (owners', principals') wealth.

Hence, the owners are forced to create and implement different incentive schemes and monitoring schemes for agents to minimize deviations. As it has been proved by many research managers (agents) work more efficiently only if they receive strong motivation such as perks, bonuses, fringe benefits, stock options, etc. If the agent should act in the best interest of the shareholder the efficiency (E a desirable effect) is based on the appropriate relationship between following factors: the agent action in the interests of principal (b), the intensity of work the agent (i) and agent remuneration or criteria on which remuneration is based (w). (Gruszecki [9], pp. 220). This is expressed by the formula:

$$
E=f(b, i, w)
$$

Regardless the large number of conducted researches concerning agency costs there are still some reservations about the role the different incentives play in managers performance and what is the best structure of mangers (directors) remunerations. Although many empirical studies claim that incentive schemes can notably increase productivity of mangers and an optimal compensation contract is a cure for the principal agent conflict, some research or even recent examples, give grounds for considering high pay-performance contracts as not reasonable ${ }^{2}$.

Therefore, it becomes increasingly interesting to test the relationship between directors' remuneration and company performance. The first part of the paper describes the different incentive incorporated in directors' remuneration package. The second part analyse current state of research with directors payperformance. Third part discusses the methodology used in the study and results obtained. The last part presents conclusions and recommendations.

\footnotetext{
${ }^{2}$ See RBS example.
} 
The research has been conducted on companies listed on London Stock Exchange and Warsaw Stock Exchange. The period taken into analysis covers the years 2007-2010.

\section{Directors remuneration}

Companies' directors can be rewarded in many ways. They receive basic salary, which includes pension contributions and prerequisites such as companies' car, club membership, etc. In addition, top executives usually obtain bonuses that are usually linked to the directors' performance. They can also be entitled to long term incentives plans usually in the form of stock options. The most commune incentive programs are:

- stock option plan,

- restricted stock plan,

- performance plan,

- deferred compensation plan,

- performance based cash compensation plan,

- profit related plan,

- company Share Option Plan.

The basic executive salary is usually determined through benchmarking method. This is conducted by remuneration committee and is based on directors' qualification, experience, past success and firm size. In the recent years, it can observe continuous increase of directors' salaries as they usually argue for competitive rewards and expect the increase on yearly basis. The new trend has been detected of new CEO (Chief Executive Directors or Managing Directors) requesting higher remuneration package than currently serving CEO.

At the end of financial year director are usually rewarded with cash bonuses. The size of the bonus is based on the company performance over the previous 12 months and is typically is related to profit measurement such as earnings before interest and tax (EBIT) or earning per share (EPS). The other commonly use measure is economic value added (EVA). In addition to the mention measures CEO contract usually have a minimum threshold that needs to be reached in order to qualify for the bonus. The bonus can be paid as a lump sum or as a percentage in relation to chosen measure. Many professional bodies are in favour of bonuses versus pay rise as bonuses are awards for realised current achievements and pay raises are increase for the future unrealised performance ${ }^{3}$.

The most popular market - orientated incentive pay is executive stock option. It allows directors to purchase the shares at a fixed price, called price or strike price. This means that if the share price reaches the higher level than strike price, the directors will gain additional profit. This approach encourages CEO and other directors to efficiently manage the company as the better company performs the higher share price can be achieved. Most of the researchers consider this method as aligning the mangers and shareholders goals ${ }^{4}$.

Some researchers stress that executive option contributed to governance failure in 1990 s and early 2000 s (e.g. Enron). That's why two new incentives have been recently introduced; restricted stock grants and performance share. Restricted stock include common stocks on which limitation has been imposes. The limitations are related to the time for which the share cannot be sold or to the certain goals that is need to be achieved before the shares can be sold. The advantage of this tactics versus option is that its value is not impacted by asymmetric $^{5}$. Performance share approach describes the situation in which the executives are award the shares only if certain criteria are achieved such as for example EPS. In this sense, the shears are regarded as rewards for past - realised achievement ${ }^{6}$.

\section{Directors payment and companies performance}

The academic interest in executive pay began in the early 80 's. Most of the researchers tried to find out relation between executive pay and firm performance. Some tried to figure out what factors influence executive compensation, how much the firm should pay or when firm should pay more to motivate executives etc. The majority research on executive compensation has been guided by agency theory. As managers are the main decision makers, it is therefore essential to motivate managers or directors through contract

\footnotetext{
3 The median bonus payment for directors in large American firms was $\$ 2,17$ million in 2007 .

${ }^{4}$ The most common stock options are for 10 years.

${ }^{5}$ It has been $12 \%$ increase in long - term restricted stock in the last 6 years.

${ }^{6}$ It can be observe that in the last 5 years the use of performance share as an element of directors remuneration increased by $36 \%$.
} 
or offer so that they bind their interests with the interests of shareholders.

Several researches undertook investigation into directors' remuneration focusing on relation between CEO pay and firm performance (Cosh et al. [3], pp. 469-492; Conyon [2], pp. 493-510; Gregg et al. [8], pp. 1-9; Kato [16], pp. 93-510; Randøy et al. [21], pp. 57-81). Jensen et al. ([14], pp. 255-268) tested pay - performance sensitivity in different variations of incentives (salaries, bonuses, stock options, etc) and found that there is a positive and statistically significant relationship between performance of a firm and managers' pay but it is rather small. The sensitivity of directors' remuneration is "about $\$ 3,25$ per $\$ 1000$ change in shareholder wealth". They also established that CEOs of larger firms have fewer stock options and enjoy less monetary incentives than CEOs from smaller firms, which is consistent with Demsetz et al. ([4], pp. 11551177) study.

Jensen et al. ([14], pp. 255-268) stress, that their findings are incoherent with optimal contracting models. They also argue that the change in shareholder wealth may not be the best indicator of CEO performance. They agree with Holmström ([11], pp. 74-91) hypotheses that optimal contracts and performance objectives for managing directors should not be only liked to main shareholder objective - increase in shareholder wealth, but also should reflect the range of consecutive measures, which will help to assess how close, is executives' choice of actions to principal's goals. It can be different accounting indicators, comparison with other CEOs from the same industry and etc.

Edmans et al. [5] proposed a multiplicative model, which incorporates the integrated theory of sensitivity and level of executives' pay in market equilibrium. The innovation in comparison to the current approach is "Firstly, motivated by first principles, consumer theory, and macroeconomic models and multiplicative preferences in the principal - agent problem" and secondly "endogenize total pay in a market equilibrium by embedding the principal-agent problem into a competitive assignment model of CEO talent" (Edmans et al. [5], p. 2).

Demsetz et al. ([4], pp. 1155-1177) as well as Jensen et al. ([14], pp. 255-268) stress that incentives schemes are very weak in big corporations probably because of weakness of corporate governance in such firms. This means linear models predict that dollar - dollar incentives should be constant across CEOs, and thus independent of size does not work in practice. This means that millions and billions of dollars (pounds, euros) might be lost every single period, which actually demands for very strong governing policies.

Hansell et al. ([10], p. 28) found that for 158 large US companies the CEO remuneration and companies' performance were moving in different directions for 2007 till - 2008 which is in line with a press rumours about excessive executive pay during the economic downturn.

The important factor influencing directors' remuneration as well as company performance is company size. A study by Rosen (1982:311-323) indicates that small difference in the quality of CEO can make a big difference in larger firms, so, larger firms try to attract the best directors for their firms. This results in higher remuneration packages in larger companies as to acquire the best CEO for the firm and to keep him or her interested in the firm.

Studies of many scholars reflect the influence of performance on director's remuneration. When the firm perform well in the market, CEOs are rewarded with compensation package. Lewellen et al. ([19], pp. 710720) have shown that CEO remuneration is strongly influence by generating profit. Gregg et al. ([8], pp. 1-9) examined UK listed 288 large firms over the period 1983-1991. They found the evidence that directors pay is related strongly with firm size. They confirmed that $50 \%$ increase in a firms revenue resulted in $10 \%$ increase in directors remuneration. Baker et al. ([1], pp. 593-616) studied the relation between managing directors' payment scheme and revenue. They found positive relation between CEO compensation and firm size. Firm that grow $10 \%$ in size usually pay $3 \%$ more to its CEOs.

Kostiuk ([18], pp. 90-105) has determined approximately the same result when he examined 73 large firm of U.S over the time 1968 to 1981. Zhou ([27], pp. 213251) examined on 755 firms which are all Canadian firms and his works also found that CEO pay is positively correlated with firm size. The same tendency has been confirmed within Japanese companies by studies of Zhou et al. ([28], pp. 665-696) and Kato ([16], pp. 93-510).

Baker et al. ([1], pp. 593-616) establish smaller pay performance sensitivity on CEO compensation in large firms. Their work also show that insignificant CEO owns amount of firm's stock's of larger firms, which 
are usually more than CEO's of small firms. This is why pay performance sensitivity is less significant in small firms but more significant in larger firms. They also highlight, that motivation strength of CEO's can be linked with the number of stock owned by CEO's. This has been established based on minor efficiency of CEO's effort rising in accordance with firm size.

The recent study of Kato et al. ([15], pp. 1-19) on Japanese firms' performance shows the influence of firm performance to CEO remuneration scheme. Their works show especially strong impact of accounting measures on directors pay but less impact of stock market performance.

Lewellen et al. ([19], pp. 710-720) examined whether any positive relation can be found between CEO compensation and firm performance. Their research on 50 US firms over the period from 1942 to 1963 shows that generating profit is strongly depends on CEO compensation.

Rosen ([22], pp. 311-323) established that the influence of ROE on CEO compensation in $0,1-0,15$ range and the elasticity of CEO pay and firm size are not significantly different from beta of 0,3 .

Gregg et al. ([8], pp. 1-9) in their study of large UK firms found that, in terms of share returns over the whole fiscal year, the influence of CEO pay on firm performance is very weak. When they examined the relation between CEO pay and firm performance again after slitting the data into 2 time period which were 1983 - 1988 and 1989 - 1991, they found that CEO pay is positively related to firm performance for the first period of time.

Finkelstein at al. ([6], pp. 179-199) looked at 1000 Fortune firms and found that CEO compensation is positively related with ROE (Return On Equity), firm size and managerial discretion such as R \& D intensity, market growth.

\section{$4 \quad$ Research methodology}

This research concentrates on investigating whether CEO remuneration is positively related to companies' size, accounting performance and to market performance. The investigation try to addresser the following questions:

- Does relation between firm size and directors' remuneration exist in selected sample - this part of the research follows the approach of Oetomo et al. [20], who examined directors' remuneration in relation to companies' size. They used book value of total assets as a proxy for firm size. Rosser et al. ([23], pp. 115-126) also used book value of total assets as firm size when they investigated the impact of firm size on CEO compensation. Following regression model is used to determine the relationship between CEO compensation on firm size:

$\mathrm{CEO}$ remuneration $=$

$\mathrm{a}+\mathrm{b}\{$ firm size (total assets ) $\}+\mathrm{e}$

- Does company performance impact directors remuneration - to answer this question Shim et al. ([25], pp. 93-116) path will be followed. They used return on equity (ROE) as a proxy for accounting performance indicator and Tobin's $\mathrm{Q}$ as a performance measurement for market factor to determine the impact of company performance on directors pay. To determine the relationship between CEO compensation on accounting factor: following regression model is used:

$\mathrm{CEO}$ compensation $=$

$\mathrm{a}+\mathrm{b}\{$ accounting factor $(\mathrm{ROE})\}+\mathrm{e}$

- ROE is calculated by dividing Net income after tax with total equity,

- net income is selected after tax and preferred stock dividends but before common stock dividends,

- preferred shares are excluded from total equity.

To determine the relationship between CEO compensation on market factor following regression model is used:

CEO compensation $=$

$\mathrm{a}+\mathrm{b}\{$ market factor (Tobin's Q) $\}+\mathrm{e}$

Here market value equals to:

$$
\text { Tobin's } \mathrm{Q}=[\mathrm{MVE}+\mathrm{DEBT}+\mathrm{PS}] / \mathrm{TA}
$$

where:

MVE - is the market value of shareholders equity,

DEBT - is the value of the firm's short - term liabilities net its short term assets plus the book value of the firms long term debt,

PS - is the liquidating value of the firm's outstanding preferred stock,

TA - is the book value of the total assets of the firm. 


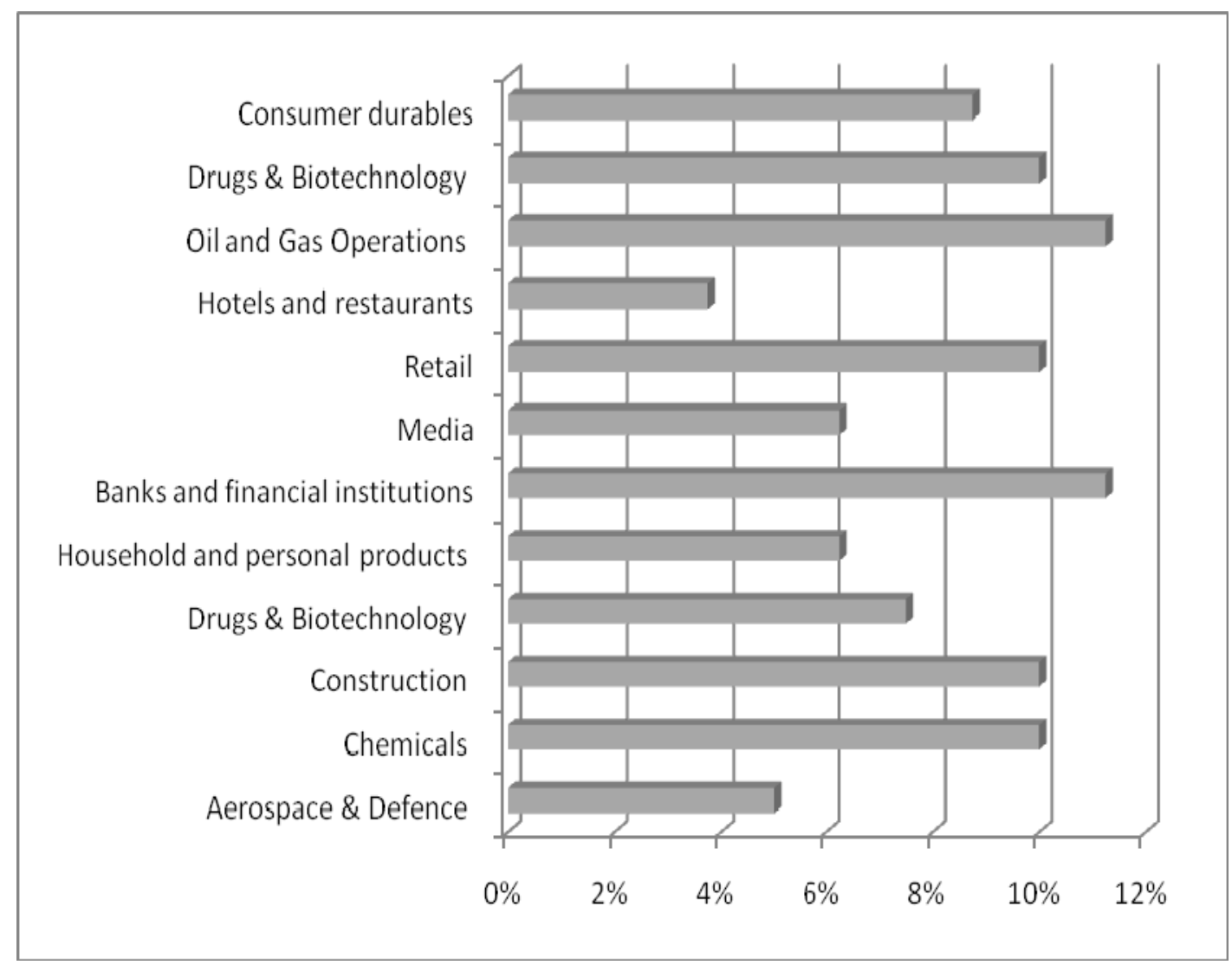

Figure 1. FTSE 100 sample (source: own work)

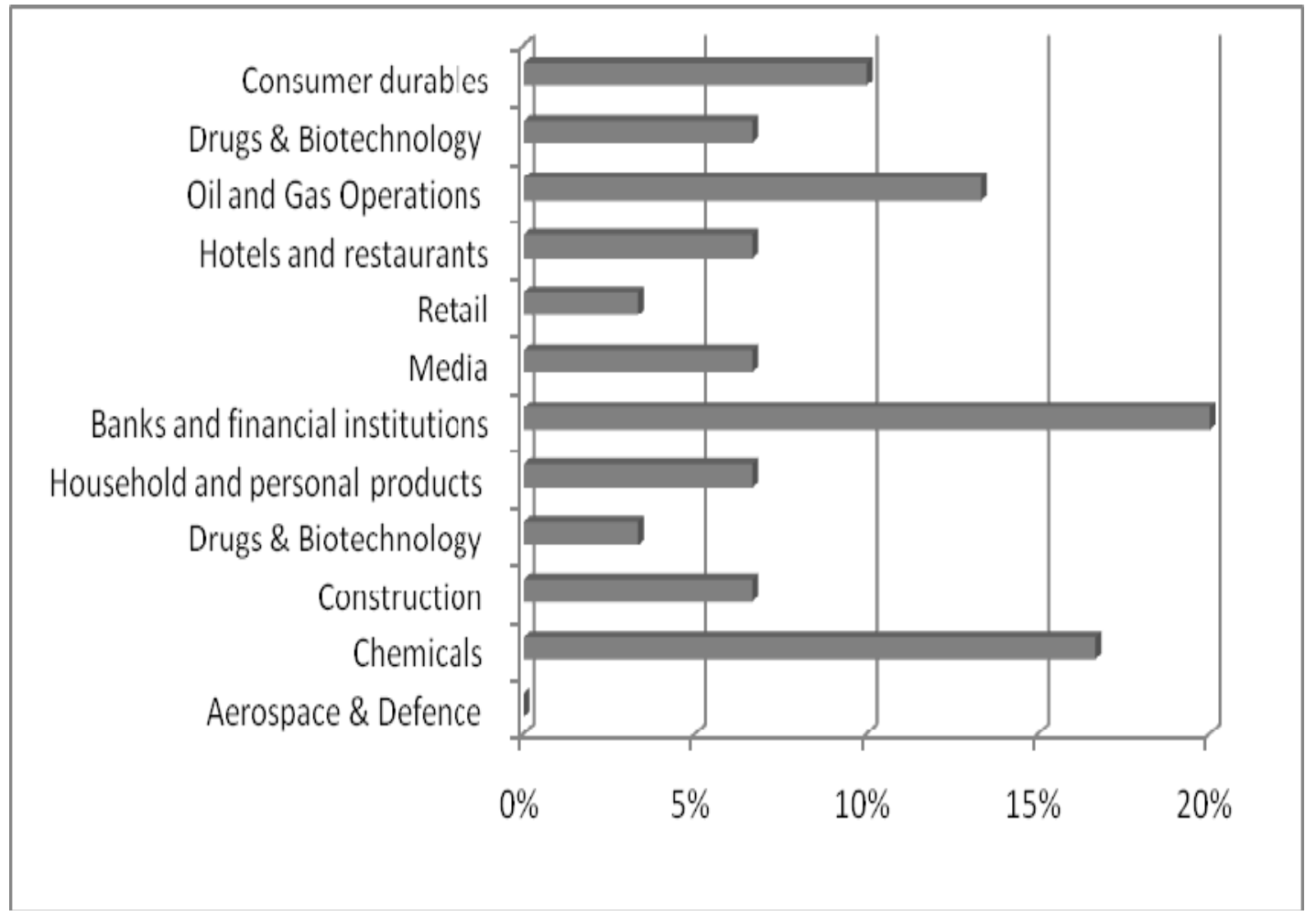

Figure 2. WSE sample structure (source: own work) 
In all three models compensation (remuneration) is consider as dependant variable. Compensation is the total of cash pay and share own by CEO (director).

\section{$5 \quad$ Data collection and findings}

At first 130 from companies has been considered for this study, but the final sample contains only 110 listed companies as some of the companies have not disclosed necessary information over investigated period. 80 companies have been randomly chosen from FTSE 100. The companies have been investigated for the period two periods: 2007-2008 and 2009-2010. The structure of the sample is presented in Fig. 1.

50 companies have been randomly selected from firms listed on Warsaw Stock Exchange. Only 30 were considered for the analysis as only those companies provide information about directors' remuneration. The structure of the sample is presented in Fig. 2. Descriptive statistics for each variable has been calculated for the purpose of data analysis. To point out the inter correlation among various measures Pearson's Correlation has been used. To verify the significance of the relation between CEO compensation and various measures, linear regression has been used. Regression models have been applied to identify relations between CEO compensation and selected factors.

Within investigated UK listed companies, the minimum full compensation was $£ 900,000$ as the highest $£ 8,9 \mathrm{~m}$. At the same, the same time the average basic salary of CEO reached $£ 981,000$. Within Polish listed companies the minimum full compensation was PLN 2,8m as the highest PLN 9,88m. At the same time the average basic salary of CEO reached PLN 865,000. The data has been obtained through content analysis of annual reports of selected companies.

Table 1, Table 2, Table 3 and Table 4 present correlation matrix between director's compensation, firm size (total assets), accounting factor (ROE) and market factor (Tobin's Q).

The research shows (see Table 1) that CEO compensation of UK based companies between 2007 and 2008 is positively related with accounting factor $(0,020)$ and market factor $(0,035)$, but negatively related with and firm size $(-0,15)$. Similar results have been obtained for 2009-2010. It shows that CEO remuneration is positively related with accounting factor $(0,022)$ and market factor $(0,035)$ though the relation with market factor is slightly lower than in previous years.

Table 1. Correlation matrix British companies for 2007-2008 (source: own work)

\begin{tabular}{|c|c|c|c|c|c|}
\hline Factor & Statistic & $\begin{array}{l}\text { Remuneration } \\
\text { (total pay) }\end{array}$ & $\begin{array}{c}\text { Firm size } \\
\text { (total assets) }\end{array}$ & $\begin{array}{c}\text { Accounting } \\
\text { Factor (ROE) }\end{array}$ & $\begin{array}{l}\text { Market factor } \\
\text { (Tobin's Q) }\end{array}$ \\
\hline $\begin{array}{l}\text { Remuneration } \\
\text { (total pay) }\end{array}$ & $\begin{array}{c}\text { Pearson Correlation } \\
\text { Sig. (2-tailed) } \\
\text { N }\end{array}$ & $\begin{array}{l}1 \\
- \\
80\end{array}$ & $\begin{array}{c}-0,015 \\
0,823 \\
80\end{array}$ & $\begin{array}{c}0,020 \\
0,783 \\
80\end{array}$ & $\begin{array}{c}0,035 \\
0,628 \\
80\end{array}$ \\
\hline $\begin{array}{c}\text { Firm size } \\
\text { (total assets) }\end{array}$ & $\begin{array}{c}\text { Pearson Correlation } \\
\text { Sig. (2-tailed) } \\
\text { N }\end{array}$ & $\begin{array}{c}-0,015 \\
0,823 \\
80\end{array}$ & $\begin{array}{c}1 \\
- \\
80\end{array}$ & $\begin{array}{c}-0,024 \\
0,793 \\
80\end{array}$ & $\begin{array}{c}-0,215^{*} \\
0,003 \\
80\end{array}$ \\
\hline $\begin{array}{l}\text { Accounting Factor } \\
\text { (ROE) }\end{array}$ & $\begin{array}{c}\text { Pearson Correlation } \\
\text { Sig. (2-tailed) } \\
\text { N }\end{array}$ & $\begin{array}{c}0,020 \\
0,783 \\
80\end{array}$ & $\begin{array}{c}-0,024 \\
0,793 \\
80\end{array}$ & $\begin{array}{c}1 \\
- \\
80\end{array}$ & $\begin{array}{c}-0,038 \\
0,598 \\
80\end{array}$ \\
\hline $\begin{array}{l}\text { Market factor } \\
\text { (Tobin's Q) }\end{array}$ & $\begin{array}{c}\text { Pearson Correlation } \\
\text { Sig. (2-tailed) } \\
\text { N }\end{array}$ & $\begin{array}{c}0,035 \\
0,628 \\
80\end{array}$ & $\begin{array}{c}-0,215^{*} \\
0,003 \\
80\end{array}$ & $\begin{array}{c}-0,038 \\
0,598 \\
80\end{array}$ & $\begin{array}{c}1 \\
- \\
80\end{array}$ \\
\hline
\end{tabular}

*correlation is significant at the 0,01 level (2-tailed) 
Table 2. Correlation matrix British companies for 2009-2010 (source: own work)

\begin{tabular}{|c|c|c|c|c|c|}
\hline Factor & Statistic & $\begin{array}{l}\text { Remuneration } \\
\text { (total pay) }\end{array}$ & $\begin{array}{c}\text { Firm size } \\
\text { (total assets) }\end{array}$ & $\begin{array}{c}\text { Accounting } \\
\text { Factor } \\
(\mathrm{ROE})\end{array}$ & $\begin{array}{l}\text { Market factor } \\
\text { (Tobin's Q) }\end{array}$ \\
\hline \multirow{3}{*}{$\begin{array}{l}\text { Remuneration } \\
\text { (total pay) }\end{array}$} & Pearson Correlation & 1 & $-0,023$ & 0,022 & 0,045 \\
\hline & Sig. (2-tailed) & - & 0,892 & 0,754 & 0,666 \\
\hline & $\mathrm{N}$ & 80 & 80 & 80 & 80 \\
\hline \multirow{3}{*}{$\begin{array}{c}\text { Firm size } \\
\text { (total assets) }\end{array}$} & Pearson Correlation & $-0,023$ & 1 & $-0,032$ & $-0,240^{*}$ \\
\hline & Sig. (2-tailed) & 0,892 & - & 0,777 & 0,003 \\
\hline & $\mathrm{N}$ & 80 & 80 & 80 & 80 \\
\hline \multirow{3}{*}{$\begin{array}{c}\text { Accounting Factor } \\
\text { (ROE) }\end{array}$} & Pearson Correlation & 0,022 & $-0,032$ & 1 & $-0,040$ \\
\hline & Sig. (2-tailed) & 0,754 & 0,777 & - & 0,578 \\
\hline & $\mathrm{N}$ & 80 & 80 & 80 & 80 \\
\hline \multirow{3}{*}{$\begin{array}{l}\text { Market factor } \\
\text { (Tobin's Q) }\end{array}$} & Pearson Correlation & 0,045 & $-0,240 *$ & $-0,040$ & 1 \\
\hline & Sig. (2-tailed) & 0,666 & 0,003 & 0,578 & - \\
\hline & $\mathrm{N}$ & 80 & 80 & 80 & 80 \\
\hline
\end{tabular}

*correlation is significant at the 0,01 level (2-tailed)

In 2009-2010 negative relation between CEO compensation and firm size $(-0,23)$ has been observe, which is in line with previous year's results. The impact is stronger in comparison to the first set of research and it is mainly due to the recession over the investigated period. Over the period of 2007-2008 the negative relation has been establish between company size and accounting factor $(-0,024)$ and company size versus market factor $(-0,215)$. Similar relation has been notice over the 2009-2010 period although the relation is slightly stronger (company size vs. accounting factor $(-0,032)$, company size vs. market factor $(-0,240)$. In both periods accounting factor (ROE) is negatively related with market factor (Tobin's Q) (2007-2008: -0,038; 2009-2010: -0,040).
Table 3 and 4 presents regression of CEO compensation on firm size. The results indicate that there is positive correlation between directors' compensation and company size. The increase of total assets by $1 \%$ over the period of 2007-2008 results in $8 \%$ increase of directors' remuneration and by $11 \%$ over $2009-2010$. It is rather surprising that in the second period the correlation is so strong over the economy downturn (20092010). T-test value of the regression coefficient of the constant is 2,213 in the first period and 3,333 in the second period. This is significant and the $t-$ test value of the regression coefficient of the independent variable, which is firm size (total assets), in this case, is 0,212 and 0,343 respectively.

Table 3. Regression on directors' compensation and firm size UK listed companies for 2007-2008 (source: own work)

\begin{tabular}{|l|c|c|c|c|c|}
\hline \multirow{2}{*}{ Model } & \multicolumn{2}{|c|}{ Unstandardised Coefficient } & $\begin{array}{c}\text { Standardised } \\
\text { Coefficient }\end{array}$ & t & \multirow{2}{*}{ Sig. } \\
\cline { 1 - 4 } & $\mathrm{B}$ & Std. Error & Beta & & \\
\hline 1 constant & 294,933 & 133,267 & - & 2,213 &, 028 \\
Firm Size (total assets) &, 000 &, 001 &, 080 &, 212 &, 823 \\
\hline
\end{tabular}


Table 4. Regression on directors' compensation and firm size UK listed companies for 2009-2010 (source: own work)

\begin{tabular}{|c|c|c|c|c|c|}
\hline \multirow[t]{2}{*}{ Model } & \multicolumn{2}{|c|}{ Unstandardised Coefficient } & $\begin{array}{c}\text { Standardised } \\
\text { Coefficient }\end{array}$ & \multirow[t]{2}{*}{$\mathrm{t}$} & \multirow[t]{2}{*}{ Sig. } \\
\hline & $\mathrm{B}$ & Std. Error & Beta & & \\
\hline 1 constant & 256,988 & 122,277 & - & 3,333 & 023 \\
\hline Firm Size (total assets) &, 000 &, 01 & ,11 & ,343 & ,799 \\
\hline
\end{tabular}

Table 5. Correlation matrix Polish companies for 2007-2008 (source: own work)

\begin{tabular}{|c|c|c|c|c|c|}
\hline Factor & Statistic & $\begin{array}{l}\text { Remuneration } \\
\text { (total pay) }\end{array}$ & $\begin{array}{c}\text { Firm size } \\
\text { (total assets) }\end{array}$ & $\begin{array}{c}\text { Accounting } \\
\text { Factor (ROE) }\end{array}$ & $\begin{array}{c}\text { Market factor } \\
\text { (Tobin's Q) }\end{array}$ \\
\hline \multirow{3}{*}{$\begin{array}{l}\text { Remuneration } \\
\text { (total pay) }\end{array}$} & Pearson Correlation & 1 & $-0,022$ & 0,027 & 0,028 \\
\hline & Sig. (2-tailed) & - & 0,833 & 0,773 & 0,688 \\
\hline & $\mathrm{N}$ & 30 & 30 & 30 & 30 \\
\hline \multirow{3}{*}{$\begin{array}{c}\text { Firm size } \\
\text { (total assets) }\end{array}$} & Pearson Correlation & $-0,022$ & 1 & $-0,028$ & $-0,225^{*}$ \\
\hline & Sig. (2-tailed) & 0,833 & - & 0,693 & 0,007 \\
\hline & $\mathrm{N}$ & 30 & 30 & 30 & 30 \\
\hline \multirow{3}{*}{$\begin{array}{l}\text { Accounting } \\
\text { Factor } \\
(\mathrm{ROE})\end{array}$} & Pearson Correlation & 0,027 & $-0,028$ & 1 & $-0,033$ \\
\hline & Sig. (2-tailed) & 0,773 & 0,693 & - & 0,558 \\
\hline & $\mathrm{N}$ & 30 & 30 & 30 & 30 \\
\hline \multirow{3}{*}{$\begin{array}{l}\text { Market factor } \\
\text { (Tobin’s Q) }\end{array}$} & Pearson Correlation & 0,028 & $-0,225^{*}$ & $-0,033$ & 1 \\
\hline & Sig. (2-tailed) & 0,688 & 0,007 & 0,558 & - \\
\hline & $\mathrm{N}$ & 30 & 30 & 30 & 30 \\
\hline
\end{tabular}

*correlation is significant at the 0,01 level (2-tailed)

Table 6. Correlation matrix Polish companies for 2009-2010 (source: own work)

\begin{tabular}{|c|c|c|c|c|c|}
\hline Factor & Statistic & $\begin{array}{c}\text { Remuneration } \\
\text { (total pay) }\end{array}$ & $\begin{array}{c}\text { Firm size } \\
\text { (total assets) }\end{array}$ & $\begin{array}{c}\text { Accounting } \\
\text { Factor (ROE) }\end{array}$ & $\begin{array}{c}\text { Market factor } \\
\text { (Tobin's Q) }\end{array}$ \\
\hline \multirow{3}{*}{$\begin{array}{l}\text { Remuneration } \\
\text { (total pay) }\end{array}$} & Pearson Correlation & 1 & $-0,020$ & 0,022 & 0,025 \\
\hline & Sig. (2-tailed) & - & 0,822 & 0,783 & 0,718 \\
\hline & $\mathrm{N}$ & 30 & 30 & 30 & 30 \\
\hline \multirow{3}{*}{$\begin{array}{c}\text { Firm size } \\
\text { (total assets) }\end{array}$} & Pearson Correlation & $-0,020$ & 1 & $-0,022$ & $-0,220 *$ \\
\hline & Sig. (2-tailed) & 0,822 & - & 0,683 & 0,004 \\
\hline & $\mathrm{N}$ & 30 & 30 & 30 & 30 \\
\hline \multirow{3}{*}{$\begin{array}{l}\text { Accounting Factor } \\
\text { (ROE) }\end{array}$} & Pearson Correlation & 0,022 & $-0,022$ & 1 & $-0,031$ \\
\hline & Sig. (2-tailed) & 0,783 & 0,683 & - & 0,598 \\
\hline & $\mathrm{N}$ & 30 & 30 & 30 & 30 \\
\hline \multirow{3}{*}{$\begin{array}{l}\text { Market factor } \\
\text { (Tobin's Q) }\end{array}$} & Pearson Correlation & 0,025 & $-0,220 *$ & $-0,031$ & 1 \\
\hline & Sig. (2-tailed) & 0,718 & 0,004 & 0,588 & - \\
\hline & $\mathrm{N}$ & 30 & 30 & 30 & 30 \\
\hline
\end{tabular}

*correlation is significant at the 0,01 level (2-tailed) 
When examining the relation between CEO compensation between 2007 and 2008 of Polish listed companies (see Table 5) a positive relation with accounting factor $(0,027)$ and market factor $(0,028)$ can be seen but negative relation with firm size $(-0,22)$. Similar results have been obtained for 2009-2010. It shows that Polish CEO remuneration is positively related with accounting factor $(0,022)$ and market factor $(0,025)$ though both relations are lower than in previous years.

In 2009-2010 negative relation between CEO compensation and firm size $(-0,20)$ has been observe, which is in line with previous years. Over the period of 20072008 the negative relation has been establish between company size and accounting factor $(-0,028)$ and company size versus market factor $(-0,225)$.

Similar relation has been notice over the 2009-2010 period although the relation is slightly stronger (company size vs. accounting factor $(-0,022)$, company size vs. market factor $(-0,220)$. In both periods, accounting factor (ROE) is negatively related with market factor (Tobin's Q) (2007-2008: -0,033; 2009-2010: -0,031).

The regression of CEO compensation on firm size (see Table 7 and Table 8) shows positive correlation of $1,5 \%$ between directors' compensation and company size over the period of $2007-2008$ and $4 \%$ positive correlation over 2009-2010.
T-test value of the regression coefficient of the constant is 2,111 in the first period and 2,233 in the second period. This is significant and the t-test value of the regression coefficient of the independent variable, which is firm size (total assets), in this case, is 0,213 and 0,233 respectively.

The results obtain within Polish companies are very similar to those noted when investigating British firms and are in line with outcomes of studies of Jansen et al. ([14], pp. 255-268), Baker et al. ([1], pp. 593-616) or Rosen ([22], pp. 311-323). In earlier studies, many scholars proved that CEO compensation is positively related with firm size. However, there is no clear indication about why firm size is correlated positively with CEO compensation. Jensen et al. ([14], pp. 593-616) assumed that maybe larger firms tend to give higher remuneration regardless of CEO abilities. Rosen ([22], pp. 311-323) has brought up similar conclusion. Baker et al. ([1], pp. 593-616) stress that usually there is greater pay performance sensitivity in larger firms and lesser significance of pay performance sensitivity in smaller firms. This allows to conclude there is that directors' compensation is positively related with firm size. Although it should be noted that further studies should be conducted to look for more factors underpinning this trend.

Table 7. Regression on directors' compensation and firm size Polish listed companies for 2007-2008 (source: own work)

\begin{tabular}{|c|c|c|c|c|c|}
\hline \multirow[t]{2}{*}{ Model } & \multicolumn{2}{|c|}{ Unstandardised Coefficient } & $\begin{array}{l}\text { Standardised } \\
\text { Coefficient }\end{array}$ & \multirow[b]{2}{*}{$\mathrm{t}$} & \multirow[b]{2}{*}{ Sig. } \\
\hline & B & Std. Error & Beta & & \\
\hline 1 constant & 222,113 & 122,227 & - & 2,113 & ,030 \\
\hline Firm Size (total assets) & ,000 & 001 & ,015 & ,250 & ,823 \\
\hline
\end{tabular}

Table 8. Regression on directors' compensation and firm size Polish listed companies for 2009-2010 (source: own work)

\begin{tabular}{|l|c|c|c|c|c|}
\hline \multicolumn{1}{|c|}{ Model } & \multicolumn{2}{|c|}{ Unstandardised Coefficient } & $\begin{array}{c}\text { Standardised } \\
\text { Coefficient }\end{array}$ & t & \multirow{2}{*}{ Sig. } \\
\cline { 1 - 4 } & $\mathrm{B}$ & Std. Error & Beta & & \\
\hline 1 constant & 236,111 & 111,707 & - & 2,233 &, 023 \\
Firm Size (total assets) &, 000 &, 01 &, 040 &, 233 &, 722 \\
\hline
\end{tabular}


There is positive a correlation between directors pay and accounting factor within British companies (Table 9 and Table 10). The research indicate that $1 \%$ increase in return on equity (accounting factor) over the period of 2007-2008 increase directors compensation by $2 \%$.and by $3 \%$ over the period of $2009-2010$. T-test value of the regression coefficient of the constant is 2,254 and 2,355 respectively, which is significant. The t-test value of the regression coefficient of the independent variable (accounting factor/return on equity) is 0,275 and 0,255 respectively.

Table 9. Regression on director's compensation and accounting factor within UK listed companies for 2007-2008 (source: own work)

\begin{tabular}{|l|c|c|c|c|c|}
\hline \multicolumn{1}{|c|}{ Model } & \multicolumn{2}{|c|}{ Unstandardised Coefficient } & \multirow{2}{*}{$\begin{array}{c}\text { Standardised } \\
\text { Coefficient }\end{array}$} & $\mathrm{t}$ & \multirow{2}{*}{ Sig. } \\
\cline { 1 - 4 } & $\mathrm{B}$ & Std. Error & Beta & & \\
\hline 1 constant & 284,916 & 126,431 & - & 2,254 &, 025 \\
Accounting Factor (ROE) & 34,447 & 125,193 &, 020 &, 275 &, 783 \\
\hline
\end{tabular}

Table 10. Regression on director's compensation and accounting factor within UK listed companies for 2009-2010 (source: own work)

\begin{tabular}{|l|c|c|c|c|c|}
\hline \multicolumn{1}{|c|}{ Model } & \multicolumn{2}{|c|}{ Unstandardised Coefficient } & $\begin{array}{c}\text { Standardised } \\
\text { Coefficient }\end{array}$ & \multirow{2}{*}{$\mathrm{t}$} & \multirow{2}{*}{ Sig. } \\
\cline { 1 - 4 } & $\mathrm{B}$ & Std. Error & Beta & & \\
\hline 1 constant & 277,116 & 132,331 & & 2,355 & \multirow{2}{*}{, 022} \\
Accounting Factor (ROE) & 24,117 & 121,281 &, 255 &, 753 \\
\hline
\end{tabular}

Table 11. Regression on director's compensation and accounting factor within Polish listed companies 2007-2008 (source: own work)

\begin{tabular}{|l|c|c|c|c|c|}
\hline \multicolumn{1}{|c|}{ Model } & \multicolumn{2}{|c|}{ Unstandardised Coefficient } & $\begin{array}{c}\text { Standardised } \\
\text { Coefficient }\end{array}$ & $\mathrm{t}$ & \multirow{2}{*}{ Sig. } \\
\cline { 1 - 4 } & $\mathrm{B}$ & Std. Error & Beta & & \\
\hline 1 constant & 254,916 & 133,431 & & 2,154 &, 029 \\
Accounting Factor (ROE) & 14,447 & 123,182 &, 010 &, 225 &, 755 \\
\hline
\end{tabular}

Table 12. Regression on director's compensation and accounting factor within Polish listed companies 2009-2010 (source: own work)

\begin{tabular}{|l|c|c|c|c|c|}
\hline \multirow{2}{*}{ Model } & \multicolumn{2}{|c|}{ Unstandardised Coefficient } & $\begin{array}{c}\text { Standardised } \\
\text { Coefficient }\end{array}$ & $\mathrm{t}$ & \multirow{2}{*}{ Sig. } \\
\cline { 1 - 4 } & $\mathrm{B}$ & Std. Error & Beta & & \\
\hline 1 constant & 263,618 & 123,233 & - & 2,554 &, 026 \\
Accounting Factor (ROE) & 15,336 & 133,812 &, 015 &, 233 &, 761 \\
\hline
\end{tabular}


The results of Polish firms show similar results (see Table 11 and Table 12). Positive relation has been established between directors pay and accounting factor. Each increase in accounting factor by $1 \%$ impacted directors' compensation with the increase of $1 \%$ over the 2007-2008 and 1,5\% over 2009-2010. T-test value of the regression coefficient of the constant is 2,154 and 2,554, which is significant and the t-test value of the regression coefficient is 0,225 and 0,233 respectively.
The results within both countries are in line with outcomes obtained by Shim et al. ([25], pp. 93-116) within high-tech and low-tech firm over the period of 19992001.

When looking at the links between directors' compensation and market factor it can be noted that a positive correlation exists between Tobin's Q and directors' remuneration within UK companies (Table 13 and Table 14).

Table 13. Regression on director's compensation and market factor within UK listed companies 2007-2008 (source: own work)

\begin{tabular}{|l|c|c|c|c|c|}
\hline \multirow{2}{*}{ Model } & \multicolumn{2}{|c|}{ Unstandardised Coefficient } & \multirow{2}{*}{$\begin{array}{c}\text { Standardised } \\
\text { Coefficient }\end{array}$} & $\mathrm{t}$ & \multirow{2}{*}{ Sig. } \\
\cline { 1 - 4 } & $\mathrm{B}$ & Std. Error & Beta & & \\
\hline 1 constant & 157,484 & 292,984 & - &, 538 &, 592 \\
Market Factor (Tobin`s Q) & 223,626 & 460,142 & 0,040 &, 468 &, 628 \\
\hline
\end{tabular}

Table 14. Regression on director's compensation and market factor within UK listed companies 2009-2010 (source: own work)

\begin{tabular}{|l|c|c|c|c|c|}
\hline \multicolumn{1}{|c|}{ Model } & \multicolumn{2}{|c|}{ Unstandardised Coefficient } & $\begin{array}{c}\text { Standardised } \\
\text { Coefficient }\end{array}$ & \multirow{2}{*}{$\mathrm{t}$} & \multirow{2}{*}{ Sig. } \\
\cline { 1 - 4 } & $\mathrm{B}$ & Std. Error & Beta & & \\
\hline 1 constant & 155,484 & 272,777 & - &, 558 &, 583 \\
Market Factor (Tobin`s Q) & 244,262 & 433,111 & 0,040 &, 466 &, 658 \\
\hline
\end{tabular}

Table 15. Regression on director's compensation and market factor within Polish listed companies 2007-2008 (source: own work)

\begin{tabular}{|c|c|c|c|c|c|}
\hline \multirow[t]{2}{*}{ Model } & \multicolumn{2}{|c|}{$\begin{array}{c}\text { Unstandardised } \\
\text { Coefficient }\end{array}$} & $\begin{array}{c}\text { Standardised } \\
\text { Coefficient }\end{array}$ & \multirow{2}{*}{$\mathrm{t}$} & \multirow{2}{*}{ Sig. } \\
\hline & B & Std. Error & Beta & & \\
\hline 1 constant & 144,444 & 272,977 & - & ,511 & ,555 \\
\hline Makter Factor (Tobin`s Q) & 209,222 & 401,421 & 0,020 & 488 & 633 \\
\hline
\end{tabular}

Table 16. Regression on director's compensation and market factor within Polish listed companies 2009-2010 (source: own work)

\begin{tabular}{|c|c|c|c|c|c|}
\hline \multirow[t]{2}{*}{ Model } & \multicolumn{2}{|c|}{$\begin{array}{c}\text { Unstandardised } \\
\text { Coefficient }\end{array}$} & $\begin{array}{c}\text { Standardised } \\
\text { Coefficient }\end{array}$ & \multirow{2}{*}{$\mathrm{t}$} & \multirow{2}{*}{ Sig. } \\
\hline & B & Std. Error & Beta & & \\
\hline 1 constant & 1614,321 & 267,121 & - & ,577 & ,572 \\
\hline Makter Factor (Tobin`s Q) & 222,343 & 422,333 & 0,025 & ,488 & 599 \\
\hline
\end{tabular}


The increase of Tobin's $\mathrm{Q}$ by 1\% increased director pay by 4\% in 2007-2008 and stay at the same level for 2009-2010. T-test value of the regression coefficient of the constant is 0,538 and 0,558 respectively and is significant. The t-test of the regression coefficient of the independent variable which is market factor (Tobin's Q) in this case, is 0,48 and 0,466 respectively.

For Polish companies the situation demonstrates the same trend. The increase of Tobin's Q by $1 \%$ boost director pay by $2 \%$ in 2007-2008 and 2,5\% 2009-2010. T-test value of the regression coefficient of the constant is 0,511 and 0,577 respectively, which is significant. The t-test value of the regression coefficient of the independent variable, which is market factor (Tobin's Q), in this case, is 0,488 and 0,511 (see Table 15 and Table 16).

The achieved results from Polish and British sample are consistent with findings of Kato et al. ([15], pp. 1-19) research on Japanese firms or Randøy et al. ([21], pp. 57-81) on Norwegian and Swedish firms. All this studies conclude positive that CEO compensation is positively related with market performance.

\section{Conclusions}

Looking at the area of directors' compensation the question is always raised how remuneration is related to directors' impute. How remuneration package needs to be structure to maximise shareholders wealth. In most cases CEO payment are correlated with companies' performance and size. This research established positive correlation between directors' payment and companies' size (book asset value) in both British and Polish listed companies. Furthermore, positive correlation has been found between firms return on capital and directors remuneration in both samples. Directors' compensation is also positively associated with market performance for both British and Polish firm. All three factors are much stronger correlated with directors remuneration within British companies. This can be associated with more developed economy, different structure of directors' remuneration, or British directors having stronger position when negotiating payment packages. All findings are consistent with the results obtained by scholars conducting research in this field.

British companies are obliged to disclose information about director's remuneration. It is strongly regarded as an element of enhancing the transparency of corporate governance. It was disappointing that many Polish listed companies do not publish information about directors' remuneration. This force researcher to limit the study to thirty companies only. It is hoped that in the future Polish companies disclose more information about directors' remuneration and it would be possible to conduct wider analysis in this field.

\section{$7 \quad$ References}

[1] Baker G., Jesen M., Murphy K.J. - Compensation and Incentives: Practice Vs Theory [in] Journal of Finance, 43(3), 1988.

[2] Conyon M. - Corporate Governance and Executive Compensation [in] International Journal of Industrial Organization, 15(4), 1997.

[3] Cosh A., Hughes A. - Executive Remuneration, Executive Dismissal and Institutional Shareholdings [in] International Journal of Industrial Organization, 15 (4), 1997.

[4] Demsetz H., Lehn K. - The structure of corporate ownership: causes and consequences [in] Journal of Political Economy, 93(66), 1985.

[5] Edmans A., Gabaix X., Landier A. - A Multiplicative Model of Optimal CEO Incentives in Market Equilibrium [in] EFA 2008 Meetings Paper Review of Financial Studies, http://papers.ssrn.com/ (accessed: 08 February 2009).

[6] Finkelstein S., Boyd B.K. - How Much Does the CEO Matter? The Role of Managerial Discretion in the Setting of CEO Compensation [in] Academy of Management Journal, Vol. 41, 1998.

[7] Gajewska-Jedwabny A. - Relacje inwestorskie i raportowanie wartości [in] Wycena i zarządzanie wartością firmy (ed. Szablewski A., Tuzimek R.), Poltext, Warszawa 2005.

[8] Gregg P., Machin S., Szymanski S. - The Disappearing Relationship between Directors' Pay and Corporate Performance [in] British Journal of Industrial Relations, Vol. 31, 1993.

[9] Gruszecki T. - Wspótczesne teorie przedsiębiorstwa. Wydawnictwo Naukowe PWN, Warszawa 2002.

[10] Hansell G., Luther L.U., Planschke F., Schatt M. Fixing what's wrong with executive compensation. The Boston Consulting Group, June 2009.

[11] Holmström J. - Moral Hazard and Observability [in] The Bell Journal of Economics 10 (1), 1979.

[12] Ignyś-Lipowiecka A. - Wybrane problemy wspótczesnego nadzoru korporacyjnego [in] Koncepcje i metody zarządzania strategicznego oraz nadzoru korporacyjnego. Doświadczenia i wyzwania (ed. Zakrzewska-Bielawska A.), C.H. Beck, Warszawa 2010.

[13] Jarzemowska M. - Nadzór korporacyjny. Polskie Wydawnictwo Ekonomiczne, Warszawa 2002. 
[14] Jensen M.C., Murphy K.J. - Performance pay and top-management incentive [in] Journal of Political Economy, April 1990.

[15] Kato T., Kubo K. - CEO Compensation and Firm Performance in Japan: Evidence from New Panel Data on Individual CEO Pay [in] Journal of Japanese and International Economics, 20(1), 2006.

[16] Kato T. - Chief Executive Compensation and Corporate Groups in Japan: New Evidence from Micro Data [in] International Journal of Industrial Organization 15 (4), 1997.

[17] Kopycińska D. - Koncepcja odpowiedzialności społecznej firmy [in] Etyka biznesu w działaniu. Doświadczenie i perspektywy (ed. Gasparski W., Dietl J.), Wydawnictwa Naukowe PWN, Warszawa 2001.

[18] Kostiuk P.F. - Firm size and executive compensation [in] The Journal of Human Resources 25(1), 1989.

[19] Lewellen W., Huntsman B. - Managerial Pay and corporate Performance [in] American Economic Review 60 (4), 1970.

[20] Oetomo T., Swan P.L. - Is it ability or size alone which explains high executive pay in large firms?: New evidence on the 'cloning' hypothesis. Working paper. University of New South Wales, Sydney, Australia 2006, available from:

http://papers.ssrn.com/ (accessed: 8 February 2009)
[21] Randøy T., Neilsen J. - Company Performance, Corporate Governance, and CEO Compensation in Norway and Sweden [in] Journal of Management and Governance (6), 2002.

[22] Rosen S. - Authority, control and the distribution of earnings [in] The Bell Journal of Economics, 13 (2), 1982.

[23] Rosser B., Canil J. - Is there a firm-size effect in CEO stock option grants? [in] Corporate Ownership and Control, Vol. 6(1), 2008.

[24] Seel F. - MPs blast 'ridiculous' pay in RBS bonus row. Timesonline 2010, available from: http://www.timesonline.co.uk/tol/news/ (accessed: 25 February 2010).

[25] Shim E., Lee, J., Joo I.K. - CEO Compensation and US High-tech and Low-tech Firms' Corporate Performance [in] Contemporary Management Research, Vol. 5, 2009.

[26] Solarz J.K. - Wptyw jakości nadzoru korporacyjnego na wartość spótki [in] Współczesne źródła wartości przedsiębiorstwa (ed. Dobiegała-Korona B., Herman A.), Difin, Warszawa 2006.

[27] Zhou X. - CEO pay, Firm Size and Corporate Performance: Evidence from Canada [in] Canadian Journal of Economics, Vol. 33, 1999.

[28] Zhou X., Swan P.L. - Performance Thresholds in managerial Incentive Contracts [in] Journal of Business, Vol. 76 (4), 2003. 